\title{
Opozycja logiki i estetyki w tradycji leibnizjańskiej i jej wpływ na koncepcję Kanta
}

W ramach badań poświęconych myśli Kanta rozróżnia się zwykle dwa zasadnicze aspekty działalności tego wybitnego myśliciela. Obok ogłoszenia szeregu prac przynoszących, jak wiadomo, gruntowną przebudowę systemu metafizyki filozof przez ponad 40 lat, początkowo jako magister legens, a od semestru letniego 1770 jako profesor zwyczajny, prowadził wykłady na Uniwersytecie w Królewcu. W przeciwieństwie do innych wielkich filozofów, w przypadku Kanta rozgraniczanie pracy wykładowcy i autora jest o tyle istotne, że treści głoszonych przez filozofa nie można ot tak po prostu uznawać za jego własne stanowisko.

Źródeł tej rozbieżności poszukiwać należy w formach pracy dydaktycznej, powszechnie obowiązujących w okresie działalności Kanta na terenie Prus. W zgodzie z panującą tradycją popartą ponadto stosownym ministerialnym zarządzeniem, wykłady uniwersyteckie miały postać lekcji prowadzonych na podstawie podręczników bądź specjalnie opracowanych i wydanych drukiem kompendiów, co w znacznym stopniu ograniczało rolę prowadzącego w zakresie możliwości publicznej repetycji myśli ich autorów. Zasadzie tej, czy jak kto woli nakazowi pozostawał wierny także Kant, choć na podstawie zachowanych notatek słuchaczy jego wykładów można bez wątpienia stwierdzić, że po początkowym okresie identyfikacji, z czasem prezentowane zagadnienia stały się przedmiotem konfrontacji. $W$ wielu rękopisach podkreśla się niezależność i dystans wykładowcy wobec tematu. Prawdą jest, że jakkolwiek leżało to w sferze planów, żadna z przygotowanych do druku prac (wyjąwszy wydaną dopiero w r. 1800 Logikę Jäschego) nie zyskała formy podręcznika. Mimo to, co najmniej już w latach osiemdziesiątych, Kant, jako profesor, miał możliwość posługiwania się spełniającymi taką właśnie funkcję opracowaniami jego systemu, dokonanymi przez Johan- 
na Schultza i Carla Schmida ${ }^{1}$. Dlaczego jednak z możliwości tej nie skorzystał?

Odpowiedź na to pytanie musi mieć charakter dwutorowy, uwzględniający obie formy działalności filozofa. Jako pedagog Kant kierował się maksyma, że wykładu nie należy ograniczać tylko do deklaratywnego przedstawienia myśli, jak czytamy w Zawiadomieniu o urzadzeniu wykładów w semestrze zimowym 1765-1766:

słuchacz „nie powinien uczyć [się] myśli, lecz myślenia. [...] Młodzieniec kończący naukę szkolną - czytamy dalej - przywykł się uczyć. Myśli on, że będzie uczyć się filozofii, co jednak jest niemożliwe, uczyć się ma on bowiem filozofowania ${ }^{2}$.

Nie tylko przytoczona maksyma, ale także uwagi poczynione przez Kanta na marginesach stosowanych kompendiów świadczą o świadomym wyborze podczas wykładów metody prezentacji tematu w formie konfrontacji stanowiska poprzedników z własnym. W tym świetle teza o rzekomej rozbieżności treści wykładów i pism nie da się do końca usprawiedliwić.

Drugi aspekt, już czysto merytoryczny, związany jest z zawartością systemu krytycznej filozofii Kanta, powszechnie określanego mianem „przewrotu w filozofii”. Nowy system nie dał się definitywnie zakwalifikować według obowiązujących jeszcze od czasów średniowiecza kryteriów rozdziału logiki i metafizyki. W strukturach uniwersyteckich przedmioty te wykładane były osobno, a doktryna Kanta nie była ani w jednoznaczny sposób logika, tzn. formalną nauką o pojęciach, sądach i wnioskach, ani tym bardziej tradycyjną metafizyką. Jak wiadomo, reformując model pierwszej i odrzucając dotychczasowe deklaracje drugiej, autor Krytyki czystego rozumu konstruuje wewnętrznie spójny i całkowicie reformatorski projekt idealizmu transcendentalnego, rozpatrując tematykę obu klasycznych dyscyplin w ramach analityki i dialektyki. Wydaje się, że oba powyższe aspekty w równej mierze zadecydowały o tym, że do końca działalności akademickiej pozostał on przy początkowo obranych kompendiach.

Podstawowe informacje dotyczące ich zestawienia zawarte są w dwóch wykładach inauguracyjnych Kanta: Neuer Lehrbegriff der Bewe-

1 Widać to wyraźnie np. w wykładach z antropologii, wydanych w 25 tomie Akademie Ausgabe. W kolejnych semestrach Kant prezentuje tu poglądy, które pochodziły $\mathrm{z}$ treści niewydanych jeszcze publikacji. W miarę, gdy publikacje te ukazywały się, nie odczuwał potrzeby powtarzania ich treści. Por. K. Kaśkiewicz, Wpływ francuskich estetyków naturalistycznych osiemnastego wieku na klasyczna estetykę niemiecka, Wydawnictwo Naukowe UMK, Toruń 2010, s. 265 i n.

2 I. Kant, Zawiadomienie o urządzeniu wykładów w semestrze zimowym 1765-1766, w: idem, Dzieła zebrane, t. 1, Pisma przedkrytyczne, przekład Translatorium Filozofii Niemieckiej Instytutu Filozofii UMK, Wydawnictwo Naukowe UMK, Toruń 2010, s. 744. 
gung und Ruhe z 1 kwietnia 1758 oraz Versuch einiger Betrachtungen über den Optimismus z 7 października 1759 r. Drugi z tych odczytów zakończony zostaje następującą wzmianką:

W nadchodzącym półroczu logikę wykładał będę, jak zwykle, wedle Meiera, metafizykę wedle Baumg artena. Według tego ostatniego również etykę. Geografię fizyczną wedle moich własnych skryptów. Czystą matematykę, którą rozpoczynam, wykładał będę w jednej godzinie, w drugiej zaś mechanikę. Obie wedle Wolffa. Podział godzin zostanie ogłoszony oddzielnie. Wiadomo już, że kurs każdej z tych nauk zakończę w jednym półroczu, jeśli okaże się to niewystarczające, nadrobię to kilkoma godzinami na początku następnego półrocza ${ }^{3}$.

Wymienione tu nazwiska, aczkolwiek w porządku historycznym należałoby je podać w odwrotnej kolejności, w decydujący sposób określają punkt wyjścia filozoficznego dyskursu Kanta. Przypomnijmy zatem pokrótce sylwetki przytoczonych autorów: 1) Christian Wolff - twórca obszernej Ontologii (1730), zyskał sławę jako propagator i systematyk teorii Leibniza, spotęgowaną odwołaniem go (z powodów religijnych) ze stanowiska profesora na czołowym podówczas pruskim uniwersytecie w Halle oraz późniejszym przywróceniem go na nie za sprawą Fryderyka II. 2) Alexander Gottlieb Baumgarten, uczeń Wolffa i początkowo "magister" w Halle, a po triumfalnym powrocie tego ostatniego profesor logiki i metafizyki na katedrze we Frankfurcie nad Odrą; autor wielokrotnie w owym czasie wznawianej Metaphysica (1739), stanowiącej podstawę wykładów Kanta. 3) Georg Friedrich Meier - także związany z Halle profesor tamtejszego filozoficznego fakultetu. Jego Auszug aus der Vernunftlehre (1752) - skrót dorównującej niemal rozmiarami Krytyce czystego rozumu (Vernunftlehre) - wykorzystywał Kant w trakcie ponad pięćdziesięciu cyklów wykładów z logiki.

W czasach Kanta studia uniwersyteckie, i to nie tylko na fakultecie filozoficznym, rozpoczynano od wykładu z logiki, traktowanej jako generalna propedeutyka wszelkich nauk. Fakt ten stwarza dogodną linię interpretacyjna, którą chciałbym w miarę możliwości posłużyć się także $\mathrm{w}$ niniejszym artykule. Za jej obraniem przemawia oczywiście również aspekt merytoryczny. W przeciwieństwie do systematyki współczesnej interesujący nas problem wzajemnej relacji logiki i estetyki pojawił się $\mathrm{w}$ początkowej fazie rozwoju doktryny królewieckiego filozofa w postaci takiej, jaką wspólnie, choć w różnej mierze nadali mu w śladowy sposób Wolff, a przede wszystkim Baumgarten i Meier, myśliciele o rodowodzie typowo racjonalistycznym, będący sukcesorami logizującej metafizyki Leibniza. Właśnie w teorii Leibniza należy poszukiwać źró-

3 I. Kant, Esej o kilku spostrzeżeniach na temat optymizmu, w: idem, Dzieła zebrane, t. 1, Pisma przedkrytyczne, s. 492. 
deł, na podstawie których sprowadzono podówczas dychotomię sądów logicznych i estetycznych do gruntu tej samej, podporządkowanej prawom ratio refleksji, choć jednocześnie trzeba podkreślić, że ostateczne rozpisanie funkcji obu sposobów poznania stanowi zasługę późniejszej koncepcji Baumgartena, twórcy nowożytnej estetyki, definiującego tę dyscyplinę jako „sztukę pięknego myślenia” lub „młodszą siostrę" (Leibnizowsko-Wolffiańskiej) logiki ${ }^{4}$.

Wiemy że Kant relacjonował to stanowisko, przedstawiając, jak wskazują deklaracje czynione podczas wykładów, obie dziedziny jako ściśle spokrewnione. W zapowiedzi cyklu z logiki (na podstawie kompendium Meiera) filozof oświadcza:

...bardzo bliskie pokrewieństwo materiału przy krytyce rozumu dostarcza okazji rzucić też okiem na kry tykę smaku, tj. es tetykę, ażeby reguły tej pierwszej zawsze używać, by objaśnić prawidła tej drugiej, a ich rozgraniczenie było środkiem lepszego rozumienia ich obu ${ }^{5}$.

Nie posiadamy niestety dokładnych informacji, jak dalece wdawał się Kant w toku wykładu w zagadnienia czysto estetyczne ${ }^{6}$, ale zarówno cytowany fragment, jak i lakoniczne refleksje w kompendium sugeruja, że stanowiły one dla niego kwestię w porównaniu z logiką raczej poboczna, co wskazywałoby na dystans, z jakim już w okresie przedkrytycznym (zapowiedź ta pochodzi z r. 1765) odnosił się on do obszernych racjonalistycznych koncepcji estetyki, rozwiniętych przez Baumgartena i Meiera. Mimo to warto zwrócić uwagę na kontekst, w jakim w przytoczonym oświadczeniu pojawia się termin „,estetyka”, gdyż właśnie tutaj tkwią źródła znaczeń, które okażą się dla Kanta wiążące w późniejszym okresie.

Po pierwsze, nauka estetyki zaliczona zostaje do "krytyki rozumu”, czyli po prostu tradycyjnej logiki w takiej funkcji, jaką przypisywali jej Wolff i Baumgarten, a za nimi bezpośredni projektodawca tej wypowiedzi, Georg Friedrich Meier. Nic zatem nie wskazuje tu jeszcze na podział przeprowadzony kilkanaście lat później na gruncie Krytyki czystego rozu$m u$, zgodnie z którym naukę tę, biorącą za przedmiot zespół twierdzeń o prawidłach zmysłowości, należy "starannie oddzielić i odróżnić" od logiki jako nauki o prawidłach intelektu, choć obie, właśnie $\mathrm{w}$ ramach „krytyki rozumu”, stanowić będą integralne składniki Transcendentalnej nauki o elementach, zawierającej projekt Kantowskiej epistemologii. Po wtóre, nosi ona miano „krytyki smaku” - określenie, jakie w swym

4 A. G. Baumgarten, Aesthetica w: Theoretische Ästhetik. Die grundlegenden Aschnitte aus Aesthetick, Leteinisch-Deutsch, Hamburg 1983, § 1. Por. M. Żelazny, Estetyka filozoficzna, Wydawnictwo Naukowe UMK, Torun 2009, s. 17 i n.

5 I. Kant, Zawiadomienie o urządzeniu wykładów w semestrze zimowym 1765-1766, w: idem, Dzieła zebrane, t. 1, Pisma przedkrytyczne, s. 737-738.

6 Przy Baumgartenowskim pojmowaniu estetyki. 
definitywnym znaczeniu pojawi się w pismach królewieckiego filozofa w na kartach Krytyki władzy sadzenia (1790), rozpatrującej w swej estetycznej części właśnie specyficzną i różną od sądów logicznych dziedzinę sądów smaku, odniesioną przede wszystkim do zjawiska piękna $\mathrm{w}$ przedmiotach przyrody lub sztuki, stwierdzanego przez nas na podstawie podmiotowego uczucia rozkoszy (Lust). W rezultacie w krytycznym systemie Kanta mamy do czynienia z dwiema wykładniami terminu estetyka. Wcześniejsza jest wykładnia epistemologiczna, wedle której jest ona nauką o naczelnych zasadach zmysłowości, abstrahującą od zakresu poznania intelektualnego w myśl założenia, że jej treścią pozostają tylko czyste i obiektywne formy percepcji (czas i przestrzeń), istotną zaś dla projektu filozofii transcendentalnej o tyle, o ile zmysłowość zawiera przedstawienia stanowiące a priori "warunek, pod którym są nam dane przedmioty". Z kolei wykładnia późniejsza, psychologiczna, definiuje ją jako refleksję związaną z podmiotowym czynnikiem przedstawienia, wyrażanym przez towarzyszące percepcji, ale posiadające tylko empiryczne źródła podmiotowe uczucie rozkoszy lub przykrości, które w efekcie nie pretenduje do powszechnej ważności, nie da się bowiem podług zasad a priori stwierdzić, czy przedmiot będzie, czy też nie będzie odpowiadał smakowi. Lecz w tym wypadku konieczna jest próba empiryczna.

W okresie przedkrytycznym oba te znaczenia nie są jeszcze oczywiście sprecyzowane. Estetyka jest wówczas dla Kanta w różnym stopniu częścią logiki, co sugerowałoby możliwość stosowania jej założeń jako pewnego sposobu poznania prawdy (znaczenie to odrzuci Kant na gruncie filozofii krytycznej), jak i krytyką smaku, odnoszącą się do percepcji piękna i wzniosłości ${ }^{7}$. Z perspektywy współczesnego rozumienia zadań estetyki szczególnie pierwsza z tych propozycji wymagałaby szczegółowych wyjaśnień kluczowych dla interpretacji kwestii pokrewieństwa jej materii z nauką logiki.

Wiemy, że bezpośrednią inspiracją deklaracji Kanta, zaliczającej, aczkolwiek - jak zobaczymy poniżej, nie bez zastrzeżeń - estetykę właśnie jako temat wykładu z logiki stanowił podręcznik Meiera, Auszug aus der Vernunftlehre, mocno akcentujący problem źródłowej współzależności obu rodzajów poznania.

Jak podkreślaliśmy, kompendium Meiera opracowane zostało w ramach szerszej, wspólnej dla myślicieli racjonalistycznych metodologii wiedzy, skoncentrowanej w swym kulminacyjnym punkcie, głównie za sprawą Leibniza, na logice, a na następnie po publikacji dzieł Baumgartena, także na estetyce - metodologii, u której podstawy leżał fundamentalny dla racjonalizmu postulat doskonałości poznania $\mathrm{w}$ ogóle. $\mathrm{W}$ tej

7 Por. I. Kant, Rozważania o uczuciu piękna i wzniosłości, przeł. D. Pakalski, M. Żelazny w: Dzieła zebrane, t. 1, Pisma przedkrytyczne. 
sytuacji postulat doskonałości wydaje się kluczem umożliwiającym zarysowanie wspólnego podłoża akcentowanego przez Meiera związku obu dyscyplin.

Zanim przejdziemy do sprecyzowania wyłaniających się tu zagadnień, warto przytoczyć refleksje Kanta, zebrane i opracowane przez E. Adickesa w tomach XV i XVI Akademie Textausgabe, a datowane $\mathrm{w}$ przybliżeniu na rok 1755 . Refleksje te przekonuja, że jeśli chodzi o problem doskonałości Kant podzielał podówczas stanowisko Meiera. Czytamy tam:

Zgodność tego co różnorodne w rzeczy, tak że tworzy ona wspólny cel, nazywamy doskonałością (refl. 1748).

W każdej doskonałości istnieje prawidło albo cel oraz zgodność do niego prowadząca. W poznaniu wyróżniamy szczególnie dwa cele: osiągnięcie wiedzy lub przyjemności lub też oba naraz. Pierwszy uzyskujemy przez poznanie wyraźne, drugi na dwa sposoby: albo przez piękno przedmiotu albo przez malowniczość wykładu. Cel drugi, ponieważ nie może być osiagnięty przez przedstawienia całkowicie wyraźne, jest estetyczną doskonałością poznania (refl. 1753).

Zestawiając powyższe fragmenty, odnajdujemy pierwsze punkty styczne. Dokonajmy więc ich krótkiego porównania.

Uwage zwraca tu przede wszystkim widoczna w obu wypadkach zbieżność pojęć doskonałości i celowości. Jak zobaczymy, zbieżność ta wcale nie jest przypadkowa i posiada głębokie uzasadnienie w tradycji filozoficznej. Czymś nowym w zestawieniu z ową tradycją jest rozróżnienie dwóch form doskonałości: logicznej i estetycznej. Tej pierwszej tak Wolff, jak i Kant przypisują status poznania wyraźnego, drugiej swoisty rodzaj „malarskości” oznaczającej piękno, i w przeciwieństwie do sfery logiki, przedstawiającej celowość rzeczy jedynie w sposób niewyraźny ${ }^{8}$. Właśnie kwestię wyraźności i niewyraźności podejmują kolejne notatki Kanta:

Wyraźność dotyczy formalnego celu poznania, natomiast [w celach] estetycznych wystarcza, że jest ono jasne, albowiem i poznanie, które jest niewyraźne, może przecież być jasne (refl. 1766).

Gdy zgodność osiągnięta zostaje podług reguł niższych władz poznawczych jest ona doskonała estetycznie. To znaczy, że zgodność tę poznajemy tylko siłą zmysłów. Wzbudza to przyjemność pochodzącą z niższych władz, jak np. znajomość poematów epickich lub malarskości opisu. Gdy przyjemność odkrywamy we władzach wyższych, jest ona równie duża, ale wyraźna i dlatego niekiedy nie tak powabna (ponownie refl. 1753).

\footnotetext{
8 Używa się też zwrotów poznanie jasne i ciemne (zob. poniżej).
} 
W zaprezentowanej tu perspektywie doskonałość nie ogranicza się wyłącznie do roli pojęcia postulującego perfekcję immanentnych podmiotowych czynności „percepcyjno-poznawczych” (jeśli można użyć takiego zwrotu), lecz jest także realnym faktem, którego należy poszukiwać w rzeczy. Zestawienie dwu tradycyjnych, proponowanych przez Meiera prawideł doskonałości wiedzy oraz doskonałości przedmiotu wiedzy, pozwala zauważyć ich zasadnicze punkty styczne. Skoncentrujmy się najpierw na postrzeganiu całego problemu z perspektywy poznania logicznego.

Jak łatwo można zauważyć, $\mathrm{w}$ obu przypadkach akcentuje się przede wszystkim doświadczenie różnorodności określające $\mathrm{w}$ równym stopniu tak każdorazowy akt poznawczy, jak i jego przedmiot. Tu Wolff także pozostaje na gruncie stanowiska Leibniza, głoszącego, że gdyby nawet przyjać możliwość wygraniczenia „pierwiastków” rzeczy, czyli substancji prostych (monad), to ich szczegółowa definicja, która musiałaby przecież polegać na odróżnieniu i klasyfikacji cech, takich jak choćby rozciągłość, kształt czy masa, byłaby niemożliwa. Według Leibniza, monady poznajemy tylko poprzez zjawisko tworzące złożony ",agregat” części, ich istnienie jest zatem efektem analizy logicznej, przyjmującej, że skoro są rzeczy złożone, to istnieć musi także coś bezwzględnie prostego, a więc jakiś właściwy „atom natury”. W tym sensie należałyby one do przedmiotu refleksji metafizycznej, natomiast w zakresie czysto epistemologicznym, obejmującym takie zasadnicze dziedziny nauki, jak np. fizyka czy przyrodoznawstwo, wszystkie czynności zarówno percepcji, jak i apercepcji dotyczyć mogą wyłącznie substancji złożonych. W konsekwencji aktywność poznania regulowana jest zamiarem systematycznego uporządkowania i objaśnienia złożoności skupiającej się w rzeczy tak, by można było zidentyfikować w niej pewien cel, tworzący określony fakt świadomości.

Leibniz, kładący, jak wiemy, jako podstawy własnego systemu zespół argumentów logicznych, sprowadza kluczowy problem weryfikacji prawidłowości ukonstytuowanych $\mathrm{w}$ świadomości faktów do dwóch fundamentalnych aksjomatów, a mianowicie zasady niesprzeczności, na mocy której stwierdzamy "dlaczego coś raczej jest niż nie jest” oraz zasady racji, łączącej się z pytaniem "dlaczego jest w sposób raczej taki niż inny". Jak zobaczymy, treść tych zasad posiada istotne znaczenie dla wykładni obu przedstawionych w podręczniku Meiera formuł doskonałości, dlatego spróbujmy bliżej sprecyzować funkcje, jakie pełnią one w zakresie Leibnizowskiej teorii wiedzy.

Zasada pierwsza wysuwa tzw. postulat identyczności, zgodnie z którym możliwość istnienia rzeczy uwarunkowana jest niesprzecznością jej własnych cech, będących, jeśli przyjąć model zdania logicznego, predykatami dotyczącymi jej jako podmiotu. Prawdę, czyli pozytywny aksjomat istnienia, uzyskujemy tu na podstawie wewnętrznej zgodno- 
ści predykatów. Analogicznie dowodem nieprawdy byłby aksjomat negatywny, wywiedziony z możliwości przypisania rzeczy orzeczeń wzajemnie się wykluczających, czyli sprzecznych, np. twierdzenia, że rzecz posiada jednocześnie cechę A i nie A. Jako że wszystko, co zawiera sprzeczność, jest fałszem, aksjomat ten zaprzecza istnieniu rzeczy, niemożliwy jest bowiem sąd, że jakaś rzecz. Może w pewnym orzeczeniu równocześnie istnieć i nie istnieć.

Tematem drugiej zasady, jest z kolei, poznanie, dlaczego zaobserwowana identyczność rzeczy, tworząca określony układ cech, jest faktem istniejącym właśnie tak, a nie inaczej. Dowieść jakiejś prawdy oznacza dla Leibniza tyle, co wyprowadzić jej identyczność, czyli zdać z tej prawdy sprawę (reddere rationem) - stąd też nazwa zasada racji. Nietrudno zauważyć, że obok deklarowanego zamiaru wyprowadzenia identyczności w postaci podania niesprzecznych cech istnienia jako racji tego istnienia, zasada ta posiada przede wszystkim charakter przyczynowy: jej zastosowanie ściśle powiązane jest $\mathrm{z}$ definicją przyczyn sprawczych, składających się na pewien konglomerat współistniejących cech, albo, jak powiada Leibniz, z postawieniem pytania o rację racji, stanowiącą podstawę zaistnienia rzeczy.

Jak zaznaczyliśmy, powyższe zasady logicznej epistemologii Leibniza obiera Meier za punkt wyjścia swych definicji doskonałości. Przypomnijmy: doskonałość poznania polegała na odkryciu zgodności tego, co jest $\mathrm{w}$ nim różnorodne, $\mathrm{z}$ pojęciem celu, albo na umiejętności podania wszystkich racji tego celu, natomiast doskonałość rzeczy była stwierdzonym mocą władz poznawczych faktem zaistnienia takiej zgodności cech bądź racji w przedmiocie. W tym kontekście zgodność rozmaitych treści poznania z celem jest faktycznym spełnieniem postulatu identyczności, w ramach którego różnorodność poznawanych cech rozpatrywana jest jako niesprzeczna, lub ściślej: każda z cech celowa dla zaistnienia przedmiotu staje się tu czynnikiem ów cel motywującym. Wiemy „po co" rzecz zawiera poszczególne elementy: właśnie dla osiągnięcia formy własnej identyczności. Według Meiera, który tu również wyraźnie nawiązuje do Leibniza, formułę identyczności należałoby jeszcze uzupełnić postulatem zasady drugiej, żądającym umiejętności podania racji dla zaobserwowanej formy celowości, czyli przeprowadzenia dedukcji nakierowanej na ukazanie przyczyn sprawczych, wyjaśniających dlaczego dana w świadomości identyczność rzeczy jest właśnie taka, a nie inna. Dopiero doprowadzony w ten sposób do końca akt poznawczy mógłby rościć pretensje do logicznej pewności, świadczącej o pełnej doskonałości wiedzy. W przeciwieństwie do tego, jeśli obserwacja jakiegoś przedmiotu bądź jego analiza nie byłaby w stanie wykryć wchodzących w grę racji, ostateczny zamiar refleksji pozostałby niezrealizowany. W konsekwencji przypadek taki kwalifikowałby się jako podstawa stwierdzenia na danym obszarze poznania mniejszej lub 
większej niedoskonałości, bowiem celowość nie dałaby się tu uzasadnić przez przyczynowość.

Obie powyższe zasady sprowadzają się $\mathrm{w}$ istocie do generalnego aksjomatu identyczności, w myśl którego predykaty, jeśli jako określenia współistniejących cech rzeczy nie są z ową rzeczą sprzeczne, przysługują jej w sposób pozytywny, w rezultacie rzecz, podmiot zdania logicznego, cechy te zawiera w sposób konieczny. Leibniz przyjmuje, że nie istnieją żadne znamiona czysto zewnętrzne, które by nie miały jakiejś podstawy w samej rzeczy. Zgodzie z tą deklaracja, orzeczenie zawsze zawarte jest już w podmiocie (praedicatum inest subjecto). Powyższa uwaga ta rozciąga się również na zasadę racji, bo tu także poszczególne racje składające się na rzecz z góry tkwią w podmiocie jako przysługujące mu i konstytuujące jego identyczność predykaty, nawet jeśli ma to miejsce w sposób czysto potencjalny. Dlatego również Meier nie oddziela wyraźnie obu zasad; doskonałość poznania jest zgodnością z celem albo zawiera racje tego celu. Oba sformułowania, będące wyrazem generalnej formuły harmonii przyczyn i celów, oznaczają więc dla niego to samo. Różnica polegałaby tu natomiast na tym, że w przeciwieństwie do postulatu niesprzeczności, badającego z punktu widzenia prawdy poznania tylko teoretyczną możliwość istnienia, zasada racji, odwołując się do analizy przyczyn sprawczych, rozpatruje rzeczywisty fakt zaistnienia czegoś, co nie tylko jest w sposób logiczny celowe, ale jest takie także w sposób realny.

W swym podręczniku Meier, wdając się w szeroko rozbudowane badania, skupia się głównie na perfekcji aparatu poznawczego. Jak już podkreślaliśmy, jego Vernunftlehre była w zamierzeniu całościowym opracowaniem racjonalistycznej metodologii wiedzy. Skoncentrujmy się tylko na najistotniejszym dla nas rezultacie tych badań.

Dla Meiera czysto logiczne rozróżnienie wszystkich napotkanych w zjawisku i składających się na jego celowość racji, a tym bardziej racji tych racji, w ostatecznym więc rozrachunku posługiwanie się $w$ procesie poznawczym zasadami logiki w ogóle, związane jest z pewnym trudnym do usunięcia ograniczeniem. Owszem, istnieją nauki, jak np. matematyka, w których na podstawie zasad logicznych możliwe jest osiągnięcie wysokiego stopnia harmonii doskonałości, ale w ogromnej większości dziedzin harmonia taka jest nieosiągalnym ideałem.

W tym kontekście nietrudno wskazać powody, dla których Meier wyraźnie oddzielił od siebie dwie formy doskonałości. Doskonałość logiczna, gwarantująca uzyskanie matematycznej pewności w kwestii harmonijnego stosunku racji i celów przedstawionych w danym fakcie świadomości, sprowadza się do prawd, wynikających z rozumowania opartego na aksjomatach Leibniza i całkowicie przez to rozumowanie dowiedzionych. Doskonałość estetyczną natomiast należałoby ujmować jako taka, która powstaje tak, jak np. w malarstwie powstaje ideał drze- 
wa. W tym ostatnim przypadku potrafimy w wyobraźni dostrzec różnorodność rozmaitych racji, których jednak nie sposób złożyć w cel czy wydedukować jako ostatecznej prawdy bezpośrednio uwarunkowanej zasadami logiki. Mamy tu bowiem do czynienia z porządkiem, który Kant zdefiniuje później jako przykład „celu naturalnego”. Dla autora Krytyki władzy sądzenia rzecz istnieje jako cel naturalny, gdy jest zarazem „przyczyną i skutkiem samej siebie”. W rezultacie przyczynowość może być $\mathrm{w}$ takim zjawisku pomyślana, ale nie może być logicznie zrozumiana'. Pozostańmy jednak na razie przy ustaleniach Meiera.

Autor Vernunftlehre, poza zastosowaniem wprowadzonego przez Baumgartena określenia doskonałości estetycznej, nie odbiega w zasadzie od pełniącej bardzo ważną funkcję w systemie Leibniza klasyfikacji tzw. idei wyraźnych i niewyraźnych. Dał zresztą temu wyraz w swych definicjach, dowodząc, jak pamiętamy, że doskonałość logiczna zawarta jest w poznaniu wyraźnym i tym różni się ona od niewyraźnej, czyli estetycznej.

Jak pisaliśmy, Leibniz dopuszcza możliwość dwojakiego rodzaju poznania: po pierwsze - "poznania wyraźnego", czyli konstruującego celowość rzeczy lub prawdę o jej racjach na drodze analizy logicznej, po drugie „poznania jasnego", które mimo że samo w sobie jest „niewyraźne", to jednak wystarcza, by dany w percepcji przedmiot nie tyle zdefiniować, odwołując się do jego wewnętrznej natury i rozdysponowania cech, co w sposób raczej zadowalający odróżnić od innych i tym samym zaliczyć do sfery faktów poznawczych. W konsekwencji, jak przekonuje (powołując się tu zresztą na Kartezjusza), mogą istnieć idee, które są zarazem jasne i ciemne. Te właśnie idee odnoszą się w pełnym zakresie do ",jakości zmysłowych", stanowiących później podstawowy obiekt zainteresowania estetyków.

W dyscyplinie tej proces syntezy intelektualnej ustępuje miejsca, przynajmniej do pewnego momentu, wiedzy intuitywnej lub, mówiąc inaczej, myślenie zastąpione zostaje przez ogląd. Według łacińskiego źródłosłowu pojęcie intuitio oznaczało po prostu ogląd. Na tej podstawie znaczenie terminu "poznanie intuitywne”, wprowadzonego do tradycji racjonalistycznej już przez Spinozę (scientia intuitiva - tj. dla Spinozy „wiedza bez dowodu"10), definiowany jest, jeśli odwołać się tu do filozoficznego słownika Eislera, jako „poznanie polegające bezpośrednio na postrzeżeniu (przedstawieniu) albo bezpośredni wgląd w pewną relację, bez posługiwania się sądami, wnioskami bądź abstrakcją"11.

9 I. Kant, Krytyka władzy sądzenia, przeł. J. Gałecki, PWN, Warszawa 2004, s. 328.

10 B. de Spinoza, Etyka w porzadku geometrycznym dowiedziona, przeł. I. Myślicki, PWN, Warszawa 1954, cz. 2, tw. 40, przyp. 2, s. 118.

11 Eislers, Handwörterbuch der Philosophie, Berlin 1922, Intuitiv, s. 316. 
Leibniz dostrzegał fakt, że tak pojmowany "świat zmysłów", złożony przecież z nieskończonej ilości wrażeń, jest nieporównanie bogatszy $\mathrm{w}$ treści poznawcze, aniżeli jego intelektualna nadbudowa, siłą rzeczy dokonująca selekcji tych treści pod względem ich wartości logicznej. Używając oryginalnej terminologii, byłby to mundus sensibilis - świat percepcji, który nasz intelekt, odwołujący się jedynie do wiedzy dyskursywnej, poznawałby tylko o tyle, o ile udałoby się przekształcić go w schemat myślowy, analogiczny do schematów wiedzy matematycznej, bo tylko ta odpowiada w sposób ścisły aksjomatycznym zasadom logiki.

Jak się jednak okazuje, także w obrębie intuitywnych treści poznania jasnego możemy wyróżnić takie, które, podobnie jak treści logiczne, posiadają dla nas mniejszą lub większą wartość. Także i tu postrzeżenie całkowicie zróżnicowane i oferujące tym samym przedstawienie celowości musiałoby zostać wyabstrahowane, tak jak w przykładzie drzewa. O wiele częściej natomiast nie potrafimy spośród całego morza wzrokowych lub słuchowych percepcji wyodrębnić tej jednej, określającej aktualny stan świadomości. Dlatego w przeciwieństwie do percepcji drzewa, które, o ile założyć dostateczne skoncentrowanie uwagi, jest dla nas faktem "jasnym”, o identyczności pozbawionej wprawdzie wyraźnych logicznych proporcji poszczególnych cech, ale jednak w jakiś sposób intuitywnie uświadamianej, to już percepcja tego samego drzewa obserwowanego z pewnej odległości, np. jako część lasu, chociażby wobec siły, jaką narzucałoby świadomości to drugie „większe” przedstawienie, zostałaby „osłabiona”, lub, jak powie Leibniz „zaciemniona”. Baumgarten napisze później:

Najmniej jasne jest takie przedstawienie, którego cechy wystarczą akurat do tego, ażeby z największym trudem odróżnić je od jednej jedynej, bardzo od niego różnej rzeczy. Wyobrażenie jest zatem dla mnie tym jaśniejsze, im łatwiej mogę je odróżnić od jak największej liczby jak najbardziej mu podobnych. A najjaśniejsze jest to, które z największą łatwością mogę odróżnić od wszystkich innych, nawet najbardziej podobnych. Najmniej ciemne jest takie przedstawienie, którego cechy wystarczają do tego, by odróżnić je z największą łatwością nie tylko od jednej jedynej, bardzo do niego podobnej rzeczy. Od im większej liczby innych, im różnorodniejszych przedstawień, przy im większym natężeniu siły przedstawienie mimo wszystko nie może być odróżnione, tym jest ono ciemniejsze. A najciemniejsze jest to, którego nawet przy największym natężeniu wszystkich swych sił nie mogę odróżnić od innego, nawet najbardziej od niego różnego ${ }^{12}$.

12 A. G. Baumgarten, Aesthetica, § 528. Por. M. Żelazny, Estetyka filozoficzna, s. 30. 
Baumgarten nawiązuje tu do Leibnizowskiej teorii tzw. „małych” bądź "ciemnych" spostrzeżeń, zgodnie z którą spostrzeżenia te moglibyśmy sobie bardzo dobrze uświadomić i dokonać nad nimi refleksji, gdyby naszego umysłu nie rozpraszała mnogość szczegółów, w obrębie którego postrzeżenia silniejsze przyćmiewają słabsze.

W systemie Leibniza świadomość prezentowana jest jako źródło całej gamy wrażeń, które, wyłączając oczywiście to, co zostaje lokalnie zamknięte $\mathrm{w}$ prawach intelektu, rozciągają się w nieskończony szereg treści jasnych, mniej jasnych, aż wreszcie zupełnie ciemnych, wreszcie nawet $\mathrm{w}$ ogóle nieuświadamianych, a mimo to wywierających wpływ na zmysły, gdyż podobnie jak "cząsteczki w fizyce" składają się one na fakt zaistnienia czegoś, co postrzegamy właśnie tak, a nie inaczej jako samo w sobie celowe. Najsłynniejszym bodaj fragmentem, ilustrującym zjawisko percepcji takich ciemnych treści świadomości, jest wielokrotnie przywoływany w pismach filozofa opis szumu morza. Na przykład w Nowych rozważaniach dotyczacych rozumu ludzkiego czytamy:

\begin{abstract}
Aby jeszcze lepiej ocenić te małe spostrzeżenia, których nie umielibyśmy w masie rozróżnić, zwykłem posługiwać się przykładem szumu lub hałasu morza, który nas uderza, gdy znajdujemy się na wybrzeżu. Aby tak słyszeć ten hałas, trzeba słyszeć najpierw elementy, z których składa się ta całość, tzn. szmer każdej fali, mimo że każdy z tych małych szmerów jest poznawalny wyłącznie $\mathrm{w}$ zmieszanym zespole wszystkich innych razem i nie dostrzeglibyśmy go, gdyby fala, która go wywołuje, była tylko jedna. Ale ruch tej fali musi jednak w pewien sposób oddziaływać i musi się mieć jakieś spostrzeżenie każdego z tych szmerów, choćby najmniejszych. Inaczej nie spostrzegłoby się szumu stu tysięcy fal, gdyż nic razy sto tysięcy nie potrafi być czymśn ${ }^{13}$.
\end{abstract}

Dokonując podsumowania dotychczasowych uwag, wypada w tym miejscu postawić dwa zasadnicze pytania: Dlaczego Meier przypisywał poznaniu niewyraźnemu, w całym jego zakresie, dotyczącym zarówno percepcji jasnych, jak i ciemnych, cechę estetycznej doskonałości? Na jakiej podstawie cecha ta może być na zasadzie analogii do harmonii logicznej identyfikowana z pojęciem piękna?

Otóż, już w koncepcji Leibniza odnaleźć można podział procesu poznawczego na dwa fundamentalne etapy. Etap pierwszy to percepcja, by użyć terminu Kanta, zmysłu wewnętrznego, taka, jak choćby w cytowanym powyżej fragmencie opisującym szum morza. Etap drugi to intelektualne poznanie, pojawiające się dopiero później i próbujące na mocy zasad logiki, z lepszym lub gorszym skutkiem, zmatematyzować fakty poprzez odniesienie ich do relacji równości racji i celów. Matema-

13 G. W. Leibniz, Nowe rozważania dotyczace rozumu ludzkiego, t. 1, przeł. J. Dąbska, PWN, Warszawa 1960, s. 15-17. 
tyzacja przedstawień zjawisk przyrody możliwa jest oczywiście tylko pod pewnymi warunkami: mógłby to być np. warunek arytmetyczny, ograniczony do obliczenia masy poszczególnych zjawisk, albo też, jeśli pozostać przy przykładzie morza, do obliczenia natężenia jego szumu w decybelach. Może również chodzić o warunek geometryczny, sprowadzający kształty zjawisk do określonych figur i porównujący w ten sposób ich wzajemne relacje przestrzenne. Pamiętamy, że doskonałość faktów zaliczonych do drugiego etapu poznania, tzn. tych konstruowanych przez matematyczno-logiczne czynności apercepcji intelektualnej, sprowadzała się do generalnego aksjomatu identyczności, zakładającego właśnie zgodność poszczególnych cech i racji z celem, czyli istniejąca w sposób taki, a nie inny rzeczą. Zgodność ta polegała na umiejętności logicznej rekonstrukcji połączenia racji w identyczność, czyli po prostu w jedność rzeczy, ukazującą zarazem przyczynę i cel jej zaistnienia.

Z drugiej strony wiemy już, że zaobserwowanie identyczności, tym razem jako efekt poznania niewyraźnego, możliwe jest także na obszarze faktów percepcji, choć, co już podkreślaliśmy, nie jest ona w tym przypadku wynikiem procesu dyskursywnego, a tylko intuitywnego, w którym zasadnicze dla Leibniza pytania "dlaczego jest” oraz „dlaczego jest tak, a nie inaczej", poddane zostają osądowi zmysłów. I tutaj właśnie działanie zmysłów wykazuje zbieżność z zasadami poznania intelektualnego. O ile bowiem to ostatnie jest matematycznym zestawieniem cech składających się wspólnie na pewną jedność, czyli pokazuje np. sumę elementarnych cząsteczek masy określającą ciągłość ruchu pewnej bryły albo też sumę kątów i odcinków tworzących trójkąt, dzięki czemu wiemy, dlaczego ruch bądź trójkąt są jednościami powstającymi ze stosunku takich, a nie innych wielkości, to również różnorodność faktów danych w percepcji, na przykład przytoczony przez Leibniza "szmer każdej fali" - raz rozważany ,jasno", a raz „ciemno" w akcie percepcji zestawiana jest $\mathrm{w}$ jedność, na podstawie której w analogiczny sposób zyskujemy przeświadczenie o specyficznej identyczności zjawiska i odkrywamy, zarówno to, że musi ono istnieć „tak, a nie inaczej”, jak i to dlaczego tak właśnie jest. Nietrudno zauważyć, że owo przeświadczenie byłoby efektem zaobserwowania pewnego porządku praw natury odpowiadającego porządkowi praw matematyczno-logicznych.

$$
* * *
$$

Być może, gdyby nie najistotniejsze dla Kanta zadanie ratowania metafizyki, znacznie wcześniej doczekalibyśmy się jego prac z zakresu estetyki. Inną sprawą jest kwestia, że trudno powiedzieć czy bez orientacji sceptycznej, wyniesionej z Krytyki czystego rozumu, byłyby one tak owocne, jak Krytyka władzy sadzenia. Wypada tu bowiem podkreślić, że to właśnie Kant, a nie Baumgarten, Meier czy inni reprezentanci racjonalizmu, stał 
się protoplastą coraz bardziej w miarę upływu czasu widocznego w myśli europejskiej nurtu estetyzacji filozofii, którego kontynuację można zauważyć choćby u Heideggera. Na pewno przesadą byłaby więc teza, że królewiecki filozof był myślicielem preferującym „suchy szkielet” reguł matematyczno-logicznych, a już na pewno nie czynił tego, tam gdzie można, a nawet trzeba się bez nich obejść. W latach tak zwanego okresu krytycznego filozof dobrze zdawał sobie sprawę, że logizacja prawdy estetycznej nie przybliża nas do jej zrozumienia, co więcej wiedzie najwyżej w ślepą uliczkę dezinterpretacji.

Powróćmy jednak do źródeł pytania o sądy smaku. Wśród wspomnianych refleksji, zanotowanych około roku 1755, odnajdujemy także taką, która zdaje się na to pytanie jednoznacznie odpowiadać, z tym że jest to odpowiedź wciąż w całości mieszcząca się w granicach zakreślonych przez racjonalizm. Czytamy tam mianowicie: „Zmysłowy osąd doskonałości nazywamy smakiem. Poznanie przedstawiane przez zmysłową władzę sądzenia jako doskonałe, nazywamy poznaniem estetycznym" (refl. 1748).

Niniejsza refleksja zamyka jednocześnie tematyczny zakres problemów poruszanych przez inspirującą podówczas Kanta teorię estetyki, rozpatrywanej zgodnie z zasadami szkoły leibnizjańskiej w ścisłym pokrewieństwie z logiką.

Zestawmy najważniejsze postulaty tej teorii w kolejności, w jakiej pojawiały się one w cytowanych notatkach:

1) Forma doskonałości zasadza się na formie celowości.

2) Celowość logiczna jest przedmiotem poznania „wyraźnego”, celowość estetyczna - „niewyraźnego", ale mimo to "jasnego".

3) Poznanie „niewyraźne" wypływa z niższych władz poznawczych (czyli ze zmysłowości, a nie z intelektu).

4) Zmysłowy osąd doskonałości (smak) opiera się na zmysłowej władzy sądzenia.

\section{The opposition of logic and aesthetics in Leibnizian tradition and its influence on Kant's conception}

\section{Keywords}

Aesthetics, logic, precritical philosophy, Baumgarten, Meier, Leibniz, Kant

One of the most importantelements of theeighteenth German philosophy referring to Leibniz' system was a distinction so-called clear and dark cognition. The first one meant cognition with the use of the logical principles of intellect. The second one - attaining the truths drawing directly from generalization of intuition 
(from Latin term "intuitio" - "intuition"). The field of philosophy concerning the dark cognition the leibnizianist Baumgarten defined as aesthetics. This area was interested not only in what we call today aesthetic values (although they constituted its essential part), but the cognition at all, the truth of which is taken from a generalization of intuition but not from the statement of systematic logical relation. Such a way of comprehending of the concept of "aesthetics", in contrast to the concept of "logic", for the last time occurs in Kant's philosophy, playing a very important part in it. 